\title{
Les Fleurs du Mal
}

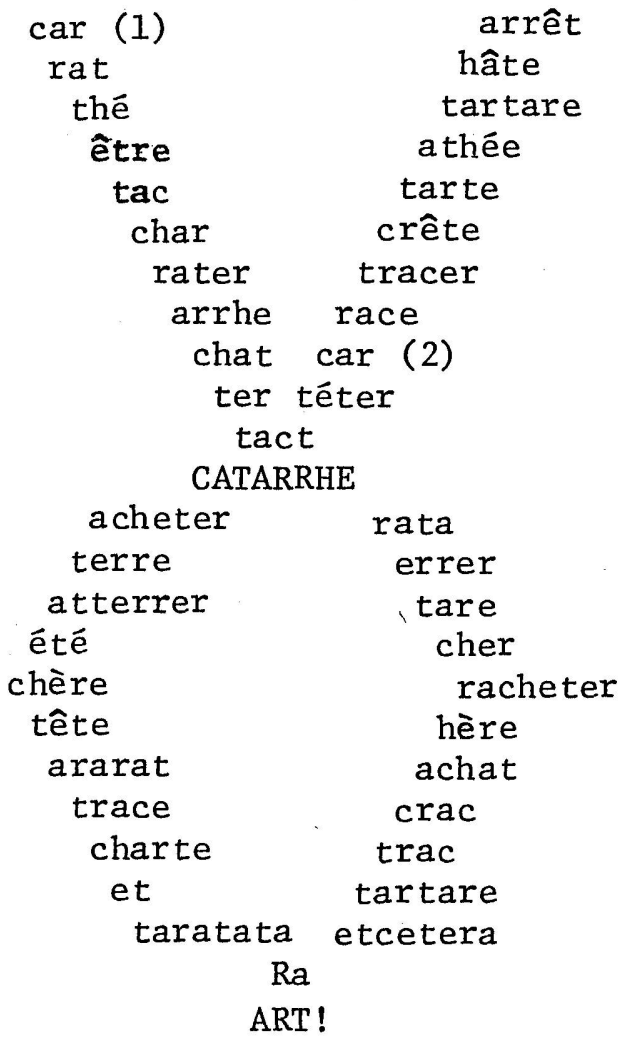

Bowling Green State University 